\title{
原子炉圧力容器用鋼A508cl.3鋼の静的および 動的弾塑性破壊靫性試験における試験片寸法の影響
}

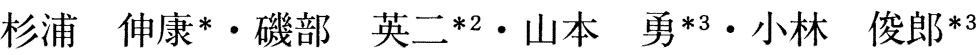

Effect of Specimen Size in Static and Dynamic Fracture Toughness

Testing in Reactor Vessel Steel A508cl.3

Nobuyasu Sugiura, Eiji Isobe, Isamu Yамamoto and Toshiro Kobayashi

Synopsis : The fracture toughness must be evaluated under the dynamic loading condition, when the materials are used for structures which are desired to a higher safety and must be taken into account of the effect of dynamic loading. Moreover, in order to obtain the valid $\mathrm{J}_{\mathrm{Ic}}$ value, a criterion about both specimen thickness $\mathrm{B}$ and ligament width $\mathrm{b}_{0}$ must be satisfied, which is called as "valid condition" and is described in the following equation.

$$
\mathrm{B}, \mathrm{b}_{0} \geq \alpha\left(\frac{\mathrm{J}_{\mathrm{in}}}{\sigma_{\mathrm{fs}}}\right),(\alpha=25)
$$

However, this equation is presented in the case of static loading and there is no assurance to be able to apply in the case of dynamic loading. Therefore, under static and dynamic loading conditions, the effects of both $B$ and $b_{0}$ on $J_{\text {in }}$ value and the flow stress $\sigma_{\mathrm{fs}}$ are investigated and the valid conditions are discussed. The results are presented that the factor $\alpha$ of the above equation is reduced as $\alpha=20$ about $b_{0}$ and is increased as $\alpha=28$ about B under dynamic loading condition.

Key words : fracture toughness ; size effect ; valid condition ; instrumented Charpy impact test ; dynamic loading.

\section{1. 緒言}

破壞靱性值は，鉄鋼材料の場合，一般に負荷速度の上昇 にともない低下する。したがって原子炉圧力容器のように 高度な安全性が要求される構造物あるいは動的な負荷が作 用する構造物においては動的負荷条件下における破壊勒性 を考虑する必要がある。そのため筆者らの一部は，簡便な 動的破壊靯性評価法であるコンピュータ援用計装化シャル ピー衝撃試験 $(\mathrm{CAI})$ システムを開発し，その有用性に関す る報告を行ってきている1) 4)。そこで残る問題は, 得られる 值のvalid性であるといえる。

ASTM E813あるいはJSME S001では，き裂発生点まで のJ積分值 $\mathrm{J}_{\text {in }}$ を破壊靶性值 $\mathrm{J}_{\mathrm{Ic}}$ とみなすために, ( 1 ) 式の“valid 基準”を規定している5)6。

$$
\mathrm{B}, \mathrm{b}_{0} \geq \alpha\left(\frac{\mathrm{J}_{\mathrm{in}}}{\sigma_{\mathrm{fs}}}\right)
$$

ここで, Bは試験片厚, $\mathrm{b}_{0}$ は試験片幅Wから予き裂長さ $\mathrm{a}_{0}$ を 差し引いたりガメント幅， $\sigma_{\mathrm{fs}}$ は流動応力， $\alpha$ は定数であり，

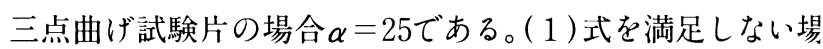
合， $\mathrm{J}_{\text {in }}$ 值は試験片寸法に依存して変化する。

一方，動的負荷の場合には，筆者らの一部がA533B鋼に ついて(1) 式の係数 $\alpha$ がBに対して $\alpha=75$ と厳しい条件が必 要であるという結果を得ている4)。しかしながらこの場合 はW=B型のシャルピー試験片を対象としており, Bおよひ $\mathrm{b}_{0}$ の独立した影響を考虑していない。

そこで本研究では，まずWすなわち $\mathrm{b}_{0}$ を固定してBを変化 させた場合の影響について調査し，次にその結果を使用し て $\mathrm{b}_{0}$ を変化させた場合の影響について調査することで,動的 負荷条件下のvalid基準を提案した。

\section{2. 実験方法}

\section{$2 \cdot 1$ 供試材および試験片}

供試材は原子炉圧力容器用鋼ASTM A508cl.3鋼(板厚 $150 \mathrm{~mm}$ )である。その化学組成および機械的性質をそれぞれ

Table 1 および 2 に示す。試験片はWおよびBを種々変化 させた三点曲げ試験片を使用した。その一覧をTable 3 に

平成 6 年 1 月17日受付 平成 6 年 5 月13日受理 (Received on Jan. 17, 1994; Accepted on May 13, 1994)

* 豊橋技術科学大学大学院生 (Graduate Student, Toyohashi University of Technology, 1-1 Hibarigaoka Tempaku-cho Toyohashi 441)

* 2 豊橋技術科学大学大学院生 (現・住友重機械(株)) (Graduate Student, Toyohashi University of Technology, now Sumitomo Heavy Industries)

* 3 豊橋技術科学大学 (Toyohashi University of Technology) 
Table 1. Chemical composition of A508cl.3 steel. (mass\%)

\begin{tabular}{c|c|c|c|c|c|c|c|c|c|c}
\hline $\mathrm{C}$ & $\mathrm{Si}$ & $\mathrm{Mn}$ & $\mathrm{P}$ & $\mathrm{S}$ & $\mathrm{Ni}$ & $\mathrm{Cr}$ & $\mathrm{Mo}$ & $\mathrm{V}$ & $\mathrm{Cu}$ & $\mathrm{Al}$ \\
\hline 0.17 & 0.26 & 1.46 & 0.003 & 0.001 & 0.76 & 0.14 & 0.51 & 0.002 & 0.01 & 0.017 \\
\hline
\end{tabular}

Table 2. Mechanical properties of A508cl.3 steel.

\begin{tabular}{c|c|c|c}
\hline $\begin{array}{c}\text { Yield } \\
\text { Strength } \\
\sigma_{\mathrm{y}}(\mathrm{MPa})\end{array}$ & $\begin{array}{c}\text { Tensile } \\
\text { Strength } \\
\sigma_{\mathrm{B}}(\mathrm{MPa})\end{array}$ & $\begin{array}{c}\text { Elongation } \\
(\%)\end{array}$ & $\begin{array}{c}\text { Reduction of } \\
\text { Area } \\
(\%)\end{array}$ \\
\hline 451 & 571 & 24 & 73 \\
\hline
\end{tabular}

Table 3. Specimen geometries and testing conditions.

(a)Static condition

\begin{tabular}{|c|c|c|c|}
\hline $\begin{array}{l}\text { Specimen } \\
\text { Width } \\
\text { (mm) }\end{array}$ & $\begin{array}{c}\text { Specimen } \\
\text { Thickness } \\
(\mathrm{mm})\end{array}$ & $\begin{array}{c}\text { Cross-head } \\
\text { Speed } \\
(\mathrm{mm} / \mathrm{min})\end{array}$ & $\begin{array}{l}\mathrm{d} \varepsilon / \mathrm{dt} \\
(1 / \mathrm{sec})\end{array}$ \\
\hline $\begin{array}{c}40 \\
20 \\
15 \\
10 \\
5 \\
\end{array}$ & $\begin{array}{c}20 \\
3,5,10,15,20 \\
20 \\
20 \\
20\end{array}$ & $\begin{array}{c}0.4 \\
0.2 \\
0.15 \\
0.1 \\
0.05\end{array}$ & $1.61 \times 10^{-4}$ \\
\hline \multicolumn{4}{|c|}{ (b)Dynamic condition } \\
\hline $\begin{array}{l}\text { Specimen } \\
\text { Width } \\
(\mathrm{mm})\end{array}$ & $\begin{array}{c}\text { Specimen } \\
\text { Thickness } \\
(\mathrm{mm})\end{array}$ & $\begin{array}{c}\text { Impact } \\
\text { Velocity } \\
\text { (m/sec) }\end{array}$ & $\begin{array}{c}\mathrm{d} \varepsilon / \mathrm{dt} \\
(1 / \mathrm{sec})\end{array}$ \\
\hline $\begin{array}{c}20 \\
15 \\
10 \\
5 \\
1.5\end{array}$ & $\begin{array}{c}20 \\
15 \\
3,5,10,15 \\
5 \\
1.5\end{array}$ & $\begin{array}{l}5.01 \\
3.77 \\
3.73 \\
2.92 \\
1.01\end{array}$ & $\begin{array}{l}2.41 \times 10^{2} \\
2.42 \times 10^{2} \\
3.59 \times 10^{2} \\
5.63 \times 10^{2} \\
1.62 \times 10^{2}\end{array}$ \\
\hline
\end{tabular}

示す。スパン間隔 $\mathrm{S}$ W $\mathrm{W}(=\mathrm{B})$ が $1.5 \mathrm{~mm}$ の $1 / 6$ サイズシャル ピー微小試験片(以下 $1 / 6$ 試験片)では $S / W=8$ と, 他のす べての試験片について $/ \mathrm{W}=4$ とした。なおこの $1 / 6$ 試験片 は, 経年劣化や照射モニタ一用として筆者らの一部が特別 に開発し，使用しているものである7。

すべての試験片について, 疲労予き裂長さ $\mathrm{a}_{0}$ が $\mathrm{a}_{0} / \mathrm{W}=0.6$ となるように疲労予き裂を導入した。1/6試験片では疲労予 き裂導入時の荷重 $\mathrm{P}_{\mathrm{f}}$ が極端に小さくなるため, Fig. 1 に示す ような治具により試験片を固定し治具全体をリガメントと して疲労負荷を行った。

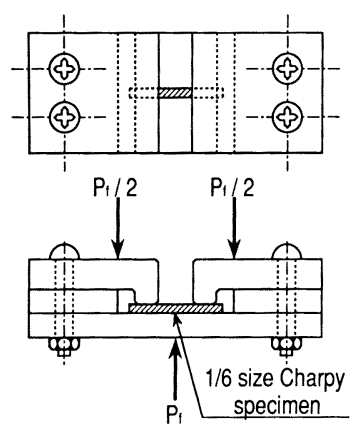

Fig. 1. Schematic illustration of the precracking apparatus.

\section{$2 \cdot 2$ 静的および動的三点曲げ破壊靭性試験}

静的試験はJSME S001に準拠 し ${ }^{6}$, 容量 $98 \mathrm{kN}$ のインスト ロン型万能試験機を用いて室温にて行った。またき裂発生 点の検出法としては直流電位差法を用いた6)。

負荷速度 $V_{0}$ は, ( 2 ) 式 ${ }^{8)}$ で表される初期状態でのき裂先端 の歪速度 $\mathrm{d} \varepsilon / \mathrm{dt}$ が一定となるように設定した。

$$
\frac{\mathrm{d} \varepsilon}{\mathrm{dt}}=\frac{6 \mathrm{WQV}_{0}}{\mathrm{~S}^{2}}
$$

ここで $\mathrm{Q}$ 塑性応力集中係数で, $\mathrm{Q}=2.57$ とした8)。Table 3 に各試験片についての負荷条件を示す。

動的試験は筆者らの一部が開発したCAIシステムにより行 った。 $\mathrm{W}(=\mathrm{B})$ が $15 \mathrm{~mm}$ 以上, $10 \mathrm{~mm}, 5 \mathrm{~mm}$ 以下の試験片に ついてそれぞれ容量490J，98J，14Jの計装化シャルピー衝 撃試験機を用いて室温にて行った。き裂発生点の検出はコ ンプライアンス変化率法 ${ }^{3 / 4)} に よ り$ 行った。その検出精度は, 過去に鉄鋼材料をはじめとする各種材料に関してストップ ブロック試験による複数試験片法と比較し，ほぼ鈍化打ち 切り点に対応すること報告しており年静的試験に用いた 直流電位差法と比較しても, 検出法の相違に起因する $\mathrm{J}_{\text {in }}$ 值 の差は小さいものと考えられる。

衝撃速度 $\mathrm{V}_{0}$ はハンマーの減速を初速度の $20 \%$ 以下をする ため, $\mathrm{W}=\mathrm{B}$ 型の試験片について (3) 式了のエネルギー条件 を満足するように決定した。

$$
\mathrm{E}_{\mathrm{app}} \geq 3 \mathrm{E}_{\mathrm{t}}
$$

ここで $\mathrm{E}_{\mathrm{app}}$ は付加エネルギー, $\mathrm{E}_{\mathrm{t}}$ は全吸収エネルギーである。 Table 3 に各試験片についての衝撃速度および (2) 式により 算出された $d \varepsilon / d t$ を示す。ここでの $d \varepsilon / d t$ 惿て定ではないが, 本論文では静的負荷と動的負荷の単純な比較として取り扱 った。

\section{$2 \cdot 3 \mathrm{~J}_{\mathrm{in}}$ 值および $\sigma_{\mathrm{fs}}$ の評価法}

$\mathrm{J}_{\text {in }}$ 值恃荷重一変位曲線下の面積 (吸収エネルギー) $\mathrm{E}_{1}$ から 算出するが, 実際の試験で測定される(みかけの) $\mathrm{E}_{1}{ }^{\prime} に は$ 試 験機の弾性変形成分が含まれている ${ }^{2) 4}$ 。そのためCAIシス テムでは，(4)式で表される弾性コンプライアンス補正を 行っている2)4。

$$
\mathrm{E}_{\mathrm{i}} \approx \mathrm{E}_{\mathrm{i}}^{\prime} \frac{\mathrm{C}_{\mathrm{s}}}{\mathrm{C}_{\mathrm{t}}}
$$

ここで $\mathrm{C}_{\mathrm{t}}$ は弾性線から測定される全コンプライアンスで, $\mathrm{C}_{\mathrm{s}}$ は試験片のコンプライアンスである。ただし（4)式は，厳 密には線形弾性域でしか成立しな(224)。

現行の静的弾塑性破壊勒性試験の規格にしたがって弾性 線から除荷線を推定寸れば゙5), $\mathrm{E}_{1}{ }^{\prime}$ の塑性成分 (添え字 $(\mathrm{pl})$ t 付す)が(5)式のように表され, 非線形な弾塑性変形に対し ても適切な $(6)$ 式の関係が得られる。 


$$
\begin{aligned}
& \mathrm{E}_{\mathrm{i}(\mathrm{pl})}=\mathrm{E}_{\mathrm{i}(\mathrm{p} 1)} \approx \mathrm{E}_{\mathrm{i}}{ }^{\prime}-\frac{1}{2} \mathrm{C}_{\mathrm{t}} \mathrm{P}^{2}{ }_{\text {in }} \\
& \mathrm{E}_{\mathrm{i}} \approx \mathrm{E}_{\mathrm{i}^{\prime}(\mathrm{pl})}+\frac{\mathrm{C}_{\mathrm{s}}}{\mathrm{C}_{\mathrm{t}}} \mathrm{E}^{\prime}{ }_{(\mathrm{e})} \approx \mathrm{E}_{\mathrm{i}}{ }^{\prime}-\frac{1}{2}\left(\mathrm{C}_{\mathrm{t}}-\mathrm{C}_{\mathrm{s}}\right) \mathrm{P}^{2}{ }_{\mathrm{in}}
\end{aligned}
$$

ここで $\mathrm{P}_{\mathrm{in}}$ はき裂発生時の荷重である。しかし，本論文で扱 う広範な試験片寸法および負荷条件に対して, 実験的な $\mathrm{C}_{\mathrm{s}}$ の算出式 ${ }^{244)}$ の適用性に疑問があるため，(6)式に理論的な $\mathrm{C}_{\mathrm{s}}$ の算出式 ${ }^{2)}$ をいることと等価である，現行の規格にした

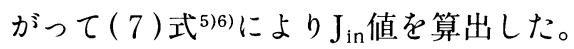

$$
\mathrm{J}_{\mathrm{in}}=\mathrm{J}_{\mathrm{in}(\mathrm{el})}+\mathrm{J}_{\mathrm{in}(\mathrm{P} \mid)}=\frac{\left(1-\nu^{2}\right) \mathrm{K}^{2}{ }_{\mathrm{in}}}{\mathrm{E}}+\frac{2 \mathrm{E}_{\mathrm{i}(\mathrm{p} 1)}}{\mathrm{Bb}}
$$

ここで $\mathrm{K}_{\text {in }}$ はき裂発生時の応力拡大係数, $\nu$ はポアソン比, Eはヤング率であり， $\nu=0.3, \mathrm{E}=200 \mathrm{GPa}$ とした。

また降伏荷重 $\mathrm{P}_{\mathrm{y}}$ およ゙最大荷重 $\mathrm{P}_{\mathrm{m}}$ をServerにより提案さ れた (8)式9に代入して $\sigma_{\mathrm{fs}}$ を算出した。

$$
\sigma_{\mathrm{fs}}=\frac{\mathrm{S}}{1.402 \mathrm{Bb}_{0}^{2}} \frac{\mathrm{P}_{\mathrm{y}}+\mathrm{P}_{\mathrm{m}}}{2}
$$

( 8 ) 式は, 三点曲げ試験片の全面降伏荷重から一軸引張応 力を推定する式である。

\section{3. 結果および考察}

\section{$3 \cdot 1$ 試験片寸法の変化によるJ ${ }_{\text {in }}$ 值および $\sigma_{\mathrm{fs}}$ の変化}

静的負荷の場合は $\mathrm{W}=20 \mathrm{~mm}$, 動的負荷の場合は $\mathrm{W}=10$ $\mathrm{mm}$ に固定し, Bのみを独立して変化させた場合の $\mathrm{J}_{\mathrm{in}}$ 值およ びの的の変化をそれぞれFig. 2 および 3 に示す。Bの減少にと もない静的および動的負荷ともに汸值が低下している。ま たFig. 2 および 3 を比較すればJ $\mathrm{I}_{\mathrm{in}}$ 值の変化と $\sigma_{\mathrm{fs}}$ の変化は対 応していることがわかる。

静的負荷の場合に $\mathrm{B}=20 \mathrm{~mm}$ に固定し,動的負荷の場合に $\mathrm{W}=\mathrm{B}$ 型の試験片を用いて, $\mathrm{b}_{0}$ を変化させた場合の $\mathrm{J}_{\text {in }}$ 值およ び $\sigma_{\mathrm{fs}}$ の変化をそれぞれFig. 4 および 5 に示す。列の減少にと もない静的および動的負荷ともに戚值が低下しており， $b_{0}$ が減少するほぞその低下は顕著である。また $\sigma_{\mathrm{fs}}$ は $\mathrm{b}_{0}$ の減少 にともない漸増しており, $\mathrm{J}_{\text {in }}$ 值の変化には対応していない。 また $1 / 6$ 試験片で $\sigma_{\mathrm{fs}}$ が急落しているが，その理由として，S/ Wの相違により Table 3 に示したd $\varepsilon / \mathrm{dt}$ 䓜下したことが考 えられる。ここで静的負荷の場合にB $=20 \mathrm{~mm}$ に固定し, 動 的負荷の場合に $\mathrm{W}=\mathrm{B}$ 型の試験片を用いており, 直接比較す ることはできないため, 次節でまずBの影響について考察す る。

\section{$3 \cdot 2$ 試験片厚の影響}

Fig. 6 に静的試験で途中除荷老行ったWが $20 \mathrm{mmでBが20}$ $\mathrm{mm}$ および $3 \mathrm{~mm}$ の試験片の限界ストレッチゾーン幅 $\mathrm{SZW}_{\mathrm{c}}$ およびき裂進展量 $\Delta \mathrm{a}$ の試験片厚方向分布を示す。Zは試験片

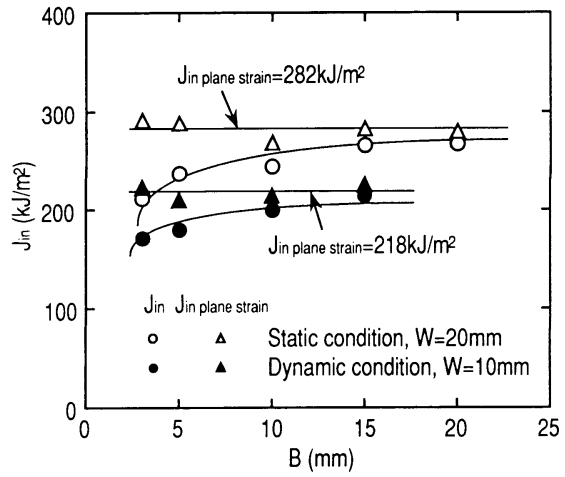

Fig. 2. Change in $J_{\text {in }}$ value with specimen thickness.

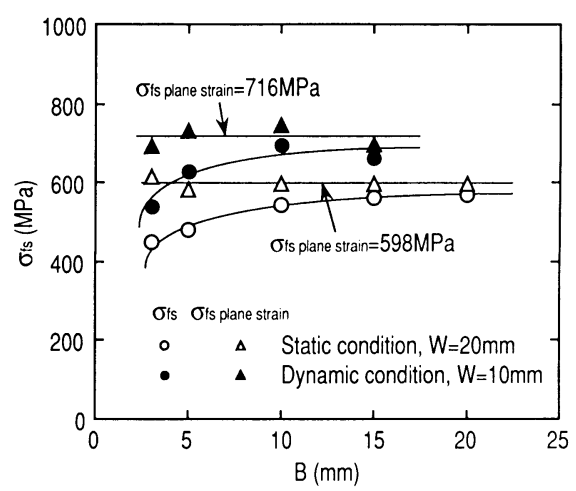

Fig. 3. Change in $\sigma_{\mathrm{fs}}$ with specimen thickness.

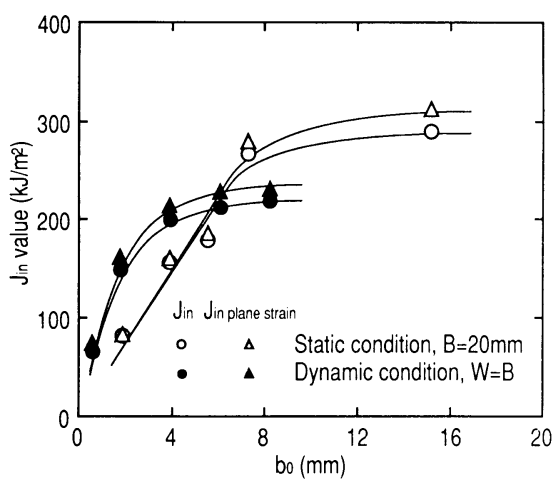

Fig. 4. Change in $\mathrm{J}_{\text {in }}$ value with ligament width.

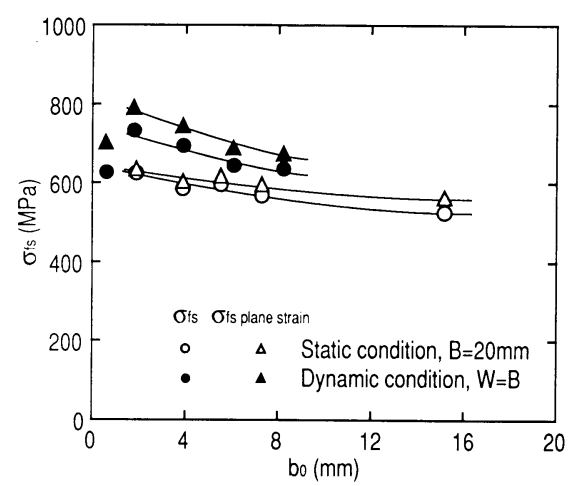

Fig. 5. Change in $\sigma_{\mathrm{fs}}$ with ligament width. 


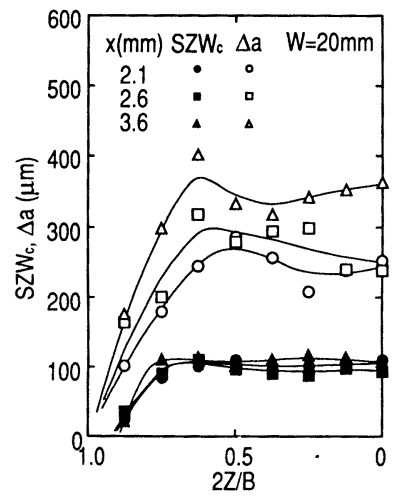

(a) $B=20 \mathrm{~mm}$

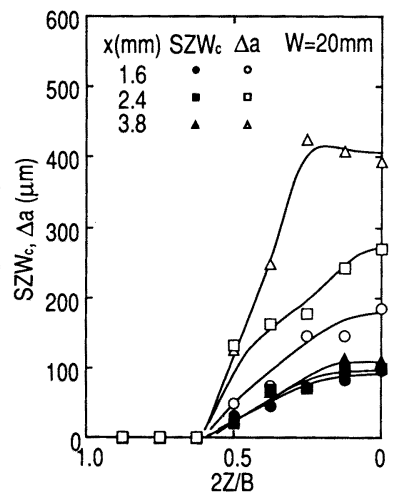

(b) $B=3 m m$
Fig. 6. Distribution of $\mathrm{SZW}_{\mathrm{c}}$ and $\Delta \mathrm{a}$ along the thickness direction.

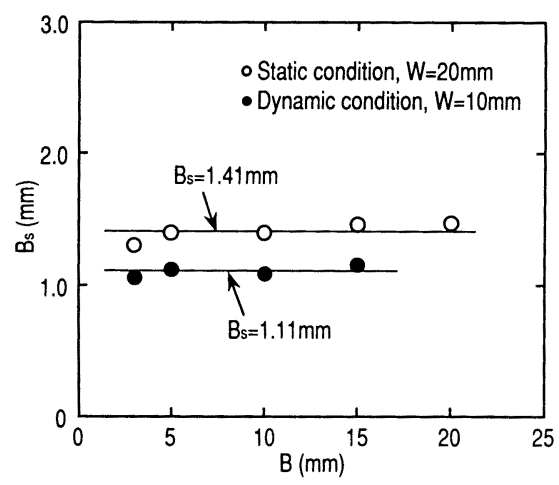

Fig. 7. Slant fracture region $B_{S}$ with specimen thickness at constant width.

中央部からの距離であり, $\mathrm{x}$ は除荷点での変位である。両試 験片とも表面近傍ではSZW,$\Delta \mathrm{a}$ ともに成長が抑制されてい る。これは試験片表面近傍では平面応力状態が支配的であ り，傾斜破壊つまりシェアリップを生じたためである。一 方, 試験片内部 (平坦破壊部) のSZW していないことがわかる。

Bを独立して変化させた各試験片について,ストレッチン グが抑制されている領域の厚さとして測定した傾斜破壊部 の厚さ $\mathrm{B}_{\mathrm{s}}$ をFig. 7 に示す。静的および動的負荷のそれぞれで $\mathrm{B}_{\mathrm{s}}$ の大きさは $\mathrm{B}$ 依存しないほぼ一定の值を示している。し たがって, Fig. 6 および 7 の結果より, 平坦破壊部が平面歪 状態にあると考えれば, Bを大きくすることでBに占める傾 斜破壊部の割合 $2 \mathrm{~B}_{\mathrm{s}} / \mathrm{B}$ が減少し, 平面歪状態が支配的にな ると考えられる。

ところで，塑性拘束を考虑した傾斜破壊と平坦破壊の混 合解析 ${ }^{10)}$ 適用することにより, 荷重成分の変化から, 平面 歪状態でのJ積分值 $\mathrm{J}_{\text {plane strain }}$ よび平面歪状態の三点曲げ

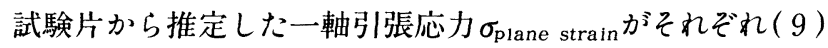
および(10)式を用いて推定可能である。

$$
\mathrm{J}_{\text {plane strain }}=\mathrm{J} /\left\{1-\left(1-\frac{1}{\mathrm{~m}^{\prime}}\right) \frac{2 \mathrm{~B}_{\mathrm{s}}}{\mathrm{B}}\right\}
$$

$$
\sigma_{\text {plane strain }}=\sigma /\left\{1-\left(1-\frac{1}{\mathrm{~m}^{\prime}}\right) \frac{2 \mathrm{~B}_{\mathrm{s}}}{\mathrm{B}}\right\}
$$

ここで $\mathrm{m}^{\prime}$ は塑性拘束係数であり, $\mathrm{a}_{0} / \mathrm{W}=0.6$ の試験片に対 して $\mathrm{m}^{\prime}=1.46 て ゙ あ る{ }^{11)}$ 。Fig. 2 および 3 中に（9）および(10)

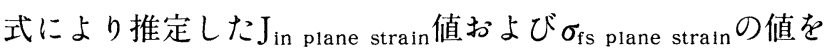
示している。Bを独立して変化させた場合には, Fig. 2 およ び 3 に示すように,いずれの值もBに依存しないほぼ一定の 值を示しており，混合解析を適用することで傾斜破壊の影 響が除去された，すなわち平面歪状態のJ積分值およびのが 推定可能であるといえる。

\section{$3 ・ 3$ リガメント幅の影響}

$\mathrm{b}_{0}$ を変化させた各試験片について測定した傾斜破壊部厚 $\mathrm{B}_{\mathrm{s}}$ をFig. 8 に示す。 $\mathrm{B}_{\mathrm{s}}$ は，ほぼb $\mathrm{b}_{0}$ に比例して変化しており，そ の変化は動的負荷の方が大きいことがわかる。

Fig. 4 および 5 中に（9）あるいは (10) 式により推定した $\mathrm{J}_{\text {in }}$ plane strain值および $\sigma_{\mathrm{fS}}$ plane strain の值を示す。これらの值の 変化は, 前節で述べたBの影響を除いた変化と考えられる。 静的負荷の場合は $\mathrm{b}_{0}=8 \mathrm{~mm}$, 動的負荷の場合 $\mathrm{b}_{0}=4 \mathrm{~mm}$ 前

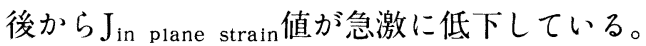

Fig. 9 に各試験片の平坦破壊部で測定したSZW 示す。1/6試験片を除けば, 静的および動的負荷それぞれで,

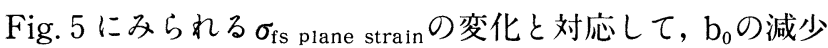
にともないSZW $\mathrm{SZ}_{\mathrm{c}}$ 漸減しているといえる。

また静的および動的負荷を比較すれば, 動的負荷でSZW がより大きく測定されているが, $\mathrm{SZW}_{\mathrm{c}}$ はき裂の発生段階前 後で引き伸ばされることが報告されており ${ }^{12)}$ ，その影響が負 荷条件により異なることが考えられる。各試験片を中央部 で切断し, Fig. 9 中に模式的に示すように鈍化角度 $\beta$ を测定 した結果, 多少のばらつきはあるものの, 静的負荷で $\beta \approx 40^{\circ}$ から動的負荷で $\beta \approx 31^{\circ}$ に変化していた。ただし $1 / 6$ 試験片で

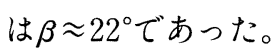

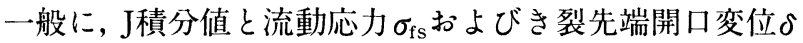
の間に(11)式の関係が成立する ${ }^{13) ~ 15) 。 ~}$

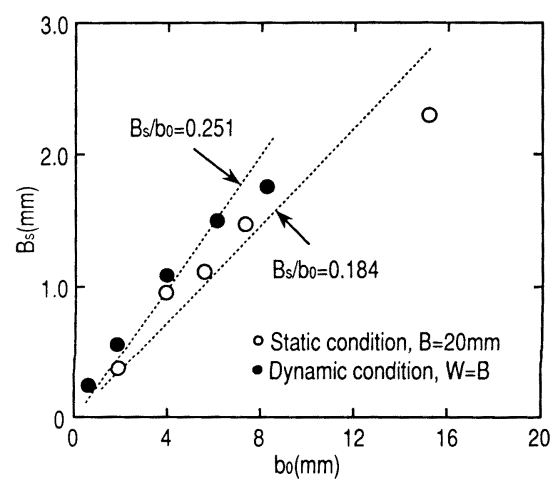

Fig. 8. Approximately linear relationship between slant fracture region $B_{s}$ and ligament width. 


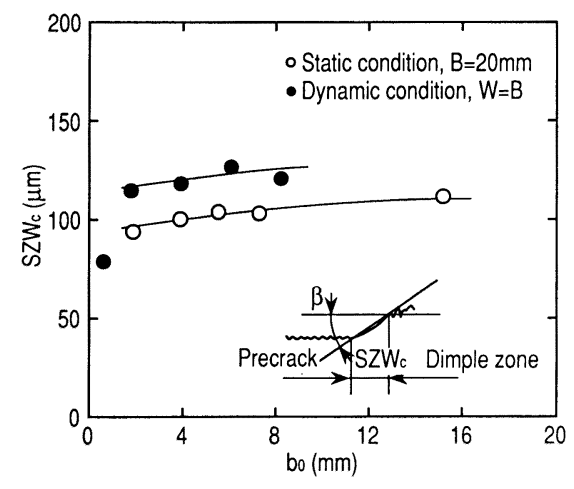

Fig. 9. Relationship between $\mathrm{SZW}_{\mathrm{c}}$ at midsection and ligament width.

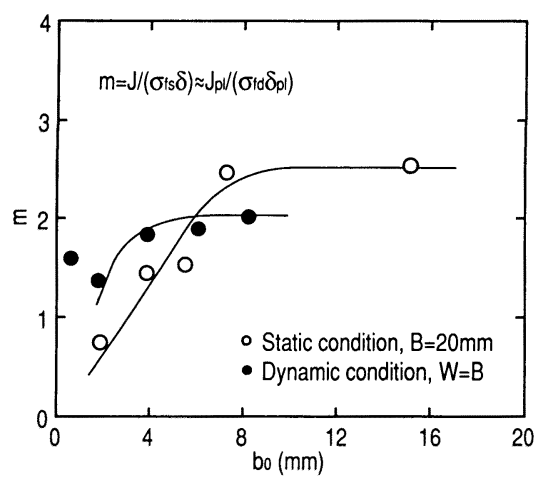

Fig.10. Change of factor $\mathrm{m}$ with ligament width.

$$
\mathrm{J}=\mathrm{m} \sigma_{\mathrm{fs}} \delta
$$

ここでmは塑性拘束および加工硬化の影響をうける係数であ $\eta \mathrm{m}=1 \sim 3$ 程度の值を示すといわれている ${ }^{13) \sim 15)}$ 。各試験

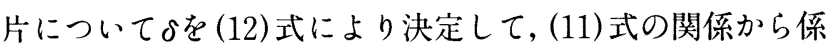
数mを逆算した結果をFig.10に示す。

$$
\delta=2 \mathrm{SZW}_{\mathrm{c}} \tan \beta
$$

ただし，実際にはFig.10中に示すように塑性成分についての み計算している。また（9)および(10)式より $\mathrm{J}_{\text {in }} / \sigma_{\mathrm{fs}}=\mathrm{J}_{\text {in plane }}$ strain $/ \sigma_{\mathrm{fs}}$ plane strainであるため, 算出した係数mはBに依存 しない。係数 $\mathrm{m}$ は静的負荷で $\mathrm{b}_{0}$ が $8 \mathrm{~mm}$ 以上の試験片で $\mathrm{m} \approx$ 2.5 , 動的負荷で $\mathrm{b}_{0}$ が $4 \mathrm{~mm}$ 以上の試験片で $\mathrm{m} \approx 2$ とほぼ 一定の值を示している。この 2 者の值の相違は, 負荷条件 の相違による加工硬化の影響を意味していると考えられる。 また係数的が一定の值を示さなかった試験片に関しては, B の減少とは無関係に $\mathrm{b}_{0}$ の減少による塑性拘束の低下の影響を 反映していると考えられる。しかしながら，試験片の平坦

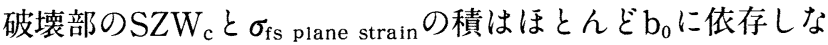
いため,より大きな試験片の係数 $\mathrm{m}$ の值が既知であれば，(11） 式により試験片寸法に依存しない $\mathrm{J}_{\text {in }}$ 值が推定可能であると 考えられる。ただし，1/6試験片に関しては，他の試験片と は明らかに異なる傾向を示しており，S/W比の相違，物理 的な試験片寸法の影響が表れていることも考えられ，今後 詳細な検討が必要であるといえる。

\section{3・4 Bのvalid基準に関する考察}

3 ・2 節の結果から, $\mathrm{J}_{\mathrm{in}}$ 值に及ぼす $\mathrm{B}$ 影響が $(9)$ 式のよ うに2 $\mathrm{B}_{\mathrm{S}} / \mathrm{B}$ 比の関数として説明されることより, Bのvalid基 準は $2 \mathrm{~B}_{\mathrm{S}} / \mathrm{B}$ 比により決定されると考えられる。しかしながら， $\mathrm{B}_{\mathrm{S}}$ は $\mathrm{B} に は$ 依存しないものの, $\mathrm{b}_{0}$ にほぼ比例して変化する ため, Bのvalid基準を $\mathrm{b}_{0}$ と独立して決定することは困難であ る。

静的負荷の場合, ( 1 ) 式においてBおよび $\mathrm{b}_{0}$ に対して $\alpha=$ 25であるから, valid基準を満足する最小の $b_{0}$ を考虑すれば, Bのvalid基準が(13)式で表される。

$$
\mathrm{B} \geq \mathrm{b}_{0}=25\left(\frac{\mathrm{J}_{\text {in }}}{\sigma_{\mathrm{fs}}}\right)
$$

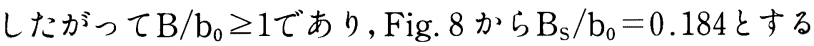
と $2 \mathrm{~B}_{\mathrm{s}} / \mathrm{B}$ 比に関して (14)式の関係が成立する。

$$
\frac{2 \mathrm{~B}_{\mathrm{s}}}{\mathrm{B}}=2 \frac{\mathrm{B}_{\mathrm{s}}}{\mathrm{b}_{0}} \frac{\mathrm{b}_{0}}{\mathrm{~B}} \leq 2 \times 0.184 \div 1 \approx 0.368
$$

つまり, 静的負荷の場合のvalid基準が $2 \mathrm{~B}_{\mathrm{S}} / \mathrm{B}$ 比を 0.368 以下 としていることがわかる。2 $\mathrm{B}_{\mathrm{s}} / \mathrm{B}=0.368$ のき(9)式より $\mathrm{J} / \mathrm{J}_{\text {plane strain }} \approx 0.884$ であり，傾斜破壊の影響は小さく抑え られているといえる。

動的負荷の場合, (14) 式の条件と Fig. 8 か $ら \mathrm{~B}_{\mathrm{s}} / \mathrm{b}_{0}=0.251$ とすれば，(15)式の関係が導かれる。

$$
\mathrm{B}=2 \frac{\mathrm{B}}{2 \mathrm{~B}_{\mathrm{s}}} \frac{\mathrm{B}_{\mathrm{S}}}{\mathrm{b}_{0}} \mathrm{~b}_{0} \geq 2 \div 0.368 \times 0.251 \mathrm{~b}_{0} \approx 1.36 \mathrm{~b}_{0} \cdots
$$

ここで， $b_{0}$ はvalid基準を満足する最小の大きさである。し たがって本供試材においては動的負荷の場合，（1）式のBに 対する係数 $\alpha$ は $\mathrm{b}_{0}$ に対する係数 $\alpha$ の約 1.36 倍の值を設定する 必要があるといえる。

以上の結果は, valid基準を満足する最小の $\mathrm{b}_{0}$ を考慮して おり,より大きな $\mathrm{b}_{0} に$ 対しては不適切であるようであるが， Fig. 8 に示す $\mathrm{B}_{\mathrm{S}}$ の変化は $\mathrm{b}_{0}$ が大きくなれば必ずしも線形に変 化していないことおよびFig. 2 および 4 を比較すればわかる ように, Bの影響は $\mathrm{b}_{0}$ の影響に比べれば小さいため, 問題は ないと考えられる。

\section{3・ $5 \mathrm{~b}_{0}$ のvalid基準に関する考察}

Fig.11に $\mathrm{J}_{\text {in }} / \sigma_{\mathrm{fs}}$ の変化を $\mathrm{b}_{0}$ に対して示す。ここでも $(9)$ お よび $(10)$ 式の関係から, $\mathrm{J}_{\mathrm{in}} / \sigma_{\mathrm{fs}}$ の值はBに依存しないことを 強調しておく。また, Fig.11中に, 静的負荷における valid 基準つまり $\alpha=25$ とした場合の（1）式を示している。静的負 荷の本試験結果に対してほぼ妥当なvalid基準を示している といえる。

ところで $\mathrm{J}_{\mathrm{in}} / \sigma_{\mathrm{fs}}$ は臨界のプロセスゾーンの大きさを代表す るパラメータであると考えられており，(1)式を満足しな い場合にHRR特異性が消失するといわれている ${ }^{16)}$ 。また(11) 式において, 係数 $\mathrm{m}$ はプロセスゾーン近傍の応力あるいは歪 


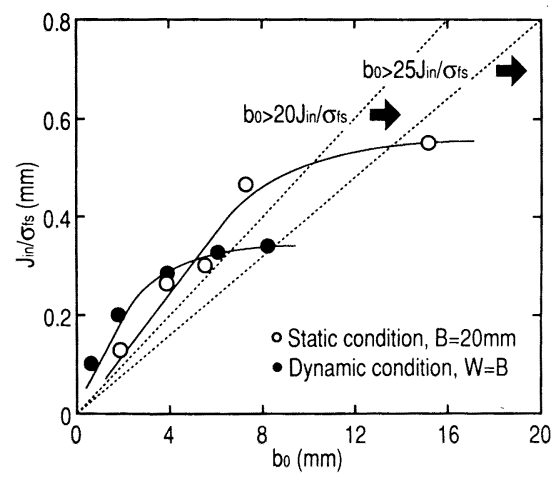

Fig.11. Change of $\mathrm{J}_{\mathrm{in}} / \sigma_{\mathrm{fs}}$ with ligament width.

分布の広がりを代表するパラメータであるといえる。した がって， $3 ・ 3$ 節で述べたように，負荷条件の相違により， 静的負荷で $\mathrm{m} \approx 2.5$ から動的負荷で $\mathrm{m} \approx 2$ と減少するのにと もない，(1)式における係数 $\alpha も \alpha=25$ から $\alpha=20$ 程度まで 緩和されると考兄られ，本供試材の動的負荷条件下におけ る $\mathrm{b}_{0}$ に対するvalid基準式として，(16)式を得る。

$$
\mathrm{b}_{0} \geq 20\left(\frac{\mathrm{J}_{\text {in }}}{\sigma_{\mathrm{fs}}}\right)
$$

また $3 ・ 4$ 節の結果から，動的負荷におけるBに対する係数 $\alpha は \alpha=20 \times 1.36 \approx 28$ 程度となり, valid基準式として（17)式 が得られる。

$$
\mathrm{B} \geq 28\left(\frac{\mathrm{J}_{\mathrm{in}}}{\sigma_{\mathrm{fs}}}\right)
$$

ところで, 緒言で述べた $\mathrm{A} 533 \mathrm{~B}$ 綱の場合には, $\mathrm{W}=\mathrm{B}$ 型の 試験片を用いてBに関して整理したため, $\alpha=75$ と厳しい結 果になったものと考えられる。この結果を $\mathrm{b}_{0} に$ 対して整理す れば $\alpha=30$ 程度である。本試験結果の $\alpha=20$ と比較すれば, まだ厳しい条件であると言わざるを得ないが，この理由と しては，2・3節で述べた弾性コンプライアンス補正によ り $\mathrm{J}_{\text {in }}$ 值が過小評価されていることおよび供試材の相違など が考えられる。今後，本論文にて行ったような解析をその 他の鉄鋼材料や様々な延性材料について適用し，動的負荷 条件下におけるvalid基準を確立する必要があると考えてい る。

\section{4. 結言}

A $508 \mathrm{cl}$. 3 綱を用いてBあるいは $\mathrm{b}_{0}$ の変化が $\mathrm{J}_{\mathrm{in}}$ 值および $\sigma_{\mathrm{fs}}$ に及ぼす影響について調查し，さらにvalid基準に考察を加 えた結果，以下のことが示された。

（1）Bを変化させた場合, 試験片表面近傍で傾斜破壊を生 ずるために $\mathrm{J}_{\mathrm{in}}$ 值と $\sigma_{\mathrm{fs}}$ が対応して変化するが，その影響は混 合解析により説明される。

（2） $\mathrm{b}_{0}$ を変化させた場合， $\mathrm{b}_{0}$ の減少にともない， $\sigma_{\mathrm{fs}}$ の漸 增と試験片内部のストレッチングの漸減が対応して変化す るが， $\mathrm{J}_{\text {in }}$ 值の変化は対応しない。

（3） Bに関するvalid基準は, 静的負荷の場合に $\mathrm{B} \geq \mathrm{b}_{0}$ とす ると $2 \mathrm{~B}_{\mathrm{s}} / \mathrm{B} \leq 0.368$ とう条件が得られ, その結果, 動的負 荷の場合には $\mathrm{B} \geq 1.36 \mathrm{~b}_{0}$ が得られた。

（4） $\mathrm{b}_{0}$ に関するvalid基準は，(11)式の係数mの変化を考 慮すれば, (1) 式の係数 $\alpha$ が静的負荷で $\alpha=25$ から動的負荷 で $\alpha=20$ 程度に緩和されると考えられる。

\section{文献}

1 ）小林俊郎，山本 勇：日本金属学会報，32 (1993), p.151

2 ）小林俊郎, 松原 等, 上田俶完 : 鉄 そ綱, 67 (1981), p.2216

3 ) 小林俊郎, 山本 勇, 新家光雄: 鉄 $飞$ 綱, 72 (1986), p.2133

4 ) 小林俊郎, 山本 勇, 上村正樹：鉄 鋼, 74 (1988), p.903

5 ) ASTM Standards E813-88, (1989)

6）日本機械学会基準 JSME S001-1992, (1992)

7 ）山本 勇, 前田太志, 小林俊郎, 森田益夫：材料, 41 (1992), p.1234

8 ) R.Standstrom and Y.Bergstrom : Met.Sci., 18 (1984), p.177

9 ) W.L.Server : J.Eng.Mat.Tech., 100 (1978), p.183

10）三好俊郎，白鳥正樹：日本機械学会論文集，48-433(A)（1982）, p.1136

11）白鳥正樹, 三好俊郎, 松下久雄：数值破壊力学, [実教出版社]

12) 武藤睦治, 坂本 勲, 関根 守: 材料, 33 (1984), p.1160

13) J.F.Knott: Met.Sci., 14 (1980), p.327

14) S.Slatcher and J.F.Knott: Mat.Sci.Eng., 82 (1986), p.37

15) C.M.Gilmore, V.Provenzano, F.A.Smidt.Jr and J.R. Hawthorne : Met.Sci., 17 (1983), p.177

16）岸本喜久男, 木村篤史, 青木 繁, 坂田 勝: 日本機械学会論文 集, 53-492(A) (1986), p.1644 